\title{
Micropropagation of Satureja obovata Lag.
}

\author{
M.L. Arrebola and O. Socorro \\ Departamento de Biología Vegetal, Facultad de Farmacia, Granada, Spain
}

A. Barceló-Muñoz and E. Simón-Pérez

Centro de Investigación y Formación Agraria, 29140 Churriana, Málaga, Spain

Fernando Pliego-Alfaro ${ }^{1}$

Departamento de Biología Vegetal, Facultad de Ciencias, Campusde Teatinos, E-29071, Málaga, Spain

Additional index words. adult, juvenile, medicinal, tissue culture, gibberellic acid, cytokinins

Abstract. A micropropagation procedure for juvenile and adult savory (Satureja obovata Lag.) explants is described. Pretreatment of the nutlets with gibberellic acid $(0.57 \mathrm{~mm}) \mathrm{did}$ not improve in vitro germination. Optimum shoot proliferation of juvenile and adult material was obtained on medium containing $2.22 \mu_{\mathrm{M}} \mathrm{N}^{6}$-benzyladenine. Rooting and acclimatization of juvenile shoots were accomplished in vivo, while adult shoots were rooted in vitro after 3 days of exposure to $4.92 \mu_{\mathrm{M}}$ indole-3-butyric acid followed by subsequent transfer to auxin-free medium. More than $95 \%$ survival of adult rooted plants was obtained during the acclimatization phase. Chemical names used: gibberellic acid $\left(\mathrm{GA}_{3}\right) ; \mathbf{N}^{6}$-benzyladenine (BA); indole-3-butyric acid (IBA); isopentenyladenine (2iP).

Savory is a subshrub native to the southern and eastern regions of Spain. This Lamiaceae member is well adapted to adverse soil and climatic conditions and plays an important role in popular medicine as.well as in apiculture in these areas (Socorro, 1987). Moreover, because of its well-developed root system, it is very useful in stabilizing soil to prevent erosion (Arrebola, 1992). Bajaj et al. (1988) have pointed out the growing interest worldwide in medicinal and aromatic plants. Savory produces an essential oil with antimicrobial activities, and thus has potential for commercial production (Cruz et al., 1990; Navarro et al., 1989). Conventionally, savory plants are propagated by seeds; however, asexual propagation methods would be highly desirable to multiply selected genotypes. The goal of this investigation was to study the response of juvenile and adult savory explants to in vitro culture as well as the establishment of a procedure for cloning adult plants.

\section{Materials and Methods}

Culture initiation-juvenile material. Mature nutlets were used as original explants. The nutlets had been obtained from individuals of a population at Torvizcón (Granada province); this population had been selected because of its outstanding performance in the apiculture industry. The nutlets were disinfested by im-

Received for publication 27 Jan. 1997. Accepted for publication 29 Apr. 1997. The cost of publishing this paper was defrayed in part by the payment of page charges. Under postal regulations, this paper therefore must be hereby marked advertisement solely to indicate this fact.

${ }^{1}$ To whom reprint requests should be addressed. mersion for $5 \mathrm{~min}$ in $0.5 \%$ sodium hypochlorite, then rinsed three times with sterile water. Prior to their establishment in culture, the nutlets were submerged in $0.57 \mathrm{mM} \mathrm{GA}_{3}$ solution for $0,2,4,8$, or $16 \mathrm{~d}$.

MS medium (Murashige and Skoog, 1962) in liquid form with paper bridge supports was used for seed germination. The $\mathrm{pH}$ was adjusted to 5.74. Twenty-five milliliter aliquots of medium were distributed in $25 \times 150-\mathrm{mm}$ glass tubes and the medium was sterilized for $15 \mathrm{~min}$ at $121^{\circ} \mathrm{C}$ and $0.1 \mathrm{MPa}$. Cultures were incubated for 5 weeks in a growth chamber at $25 \pm 1{ }^{\circ} \mathrm{C}$ under a 16 -h photoperiod (45 $\mu \mathrm{mol} \cdot \mathrm{m}^{-2} \cdot \mathrm{s}^{-1}$ irradiance from Gro-lux fluorescent lamps.

Culture initiation-adult material. Actively growing shoots from plants that had flowered in a screenhouse were used as source material. Nodal sections with two lateral buds were disinfested for $10 \mathrm{~min}$ in $0.5 \%$ sodium hypochlorite and rinsed three times with sterile water prior to culture in solid MS medium supplemented with $2.22 \mu \mathrm{M}$ BA. Incubation conditions were the same as indicated for seeds.

Shoot multiplication. Three- to 4-cm juvenile shoots obtained following seed germination were divided into nodal sections $(1 \mathrm{~cm}$ long) with two axillary buds and transferred to multiplication medium (MS medium) with BA supplements $(0,1.11,2.22,4.44 \mu \mathrm{M})$ and 8 $\mathrm{g} \cdot \mathrm{L}^{-1}$ Difco Bacto-agar.

Using mature nodal sections with two lateral buds, a comparative study tested the effects on shoot proliferation of zeatin, 2iP, and BA at $2.22 \mu \mathrm{M}$, as supplements to MS medium gelled with $8 \mathrm{~g} \cdot \mathrm{L}^{-1}$ Difco Bacto-agar.

Incubation conditions for both juvenile and adult materials were the same as indicated for seed germination. Subculture interval was 4 weeks. Data taken included main shoot length, number and length of axillary shoots, number of leaves, and number of roots. Moreover, cultures were classified as normal or hyperhydrated.

Rooting. For in vitro rooting of juvenile shoots, the basal solid medium was supplemented with IBA at 2.46 and $4.92 \mu \mathrm{M}$, and BA was excluded. Data taken and experimental conditions were the same as indicated for multiplication experiments. The culture period for in vitro rooting was 5 weeks; afterward, rooted shoots were transferred to the greenhouse. For ex vitro rooting, microcuttings were taken directly from the multiplication medium to the greenhouse. One-centimeter microcuttings were used in all cases.

Adult shoots were rooted in basal medium or by using the procedure developed for avocado (Perseaamericana) (Barceló, 1995), e.g., $3 \mathrm{~d}$ of exposure to $4.92 \mu \mathrm{M}$ IBA in gelled or liquid MS medium ( $5 \mathrm{~mL}$ ) in a rotor (TC-8; New Brunswick Scientific, N.J.) at $5 \mathrm{rpm}$, with macroelements at one-third, followed by subsequent transfer to the same medium ( 25 $\mathrm{mL}$ ) without auxin, but supplemented with 1 $\mathrm{g} \cdot \mathrm{L}^{-1}$ activated charcoal. Shoots in the rotor were placed as slants. Microcuttings used were $1 \mathrm{~cm}$ long with two nodes.

Acclimatization. Juvenile microcuttings, rooted or nonrooted, were transferred in the spring to a sphagnum peat substrate (Substrat1 , Triohum). Trays were maintained in a tunnel with a fog system for 3 weeks under $90 \%$ to $100 \%$ relative humidity $(\mathrm{RH})$ and $110-120$ $\mu \mathrm{mol} \cdot \mathrm{m}^{-2} \cdot \mathrm{s}^{-1}$ irradiance. Afterward, plants were transferred to another tunnel without fog for 2 weeks. After transplanting to 9-cm-diameter pots, plants were moved to open benches in the greenhouse with $55 \%$ to $60 \%$ RH for 5 weeks. Finally, they were transplanted to $16-\mathrm{cm}$ pots in a 2 sphagnum peat : 2 soil : 1 sand mixture and placed in a screenhouse with 50\% shade. The temperature range in the greenhouse was 15 to $30^{\circ} \mathrm{C}$.

Adult rooted or nonrooted plants were acclimatized following the same procedure, although in this case the substrate used was a 1 sphagnum peat : 1 sand mixture.

Statistical analysis. Fifteen to 20 shoots per treatment were used in multiplication experiments, and they were subcultured at least three times. In rooting experiments, 50 shoots were used per treatment. Data were analyzed using the Statgraphics Program. Normally distributed variables were analyzed by one-way analysis of variance and the Barlett test for homogeneity of variances, while for binomial distributions the $\chi^{2}$ test was chosen (Sokal and Rohlf, 1981).

\section{Results and Discussion}

Culture initiation. Juvenile plants were obtained following seed germination in vitro. Gibberellins play an important role in breaking embryo dormancy. In hazelnut embryos, they seem to be involved in mobilization of reserve substances as well as in the cotyledonary expansion that is responsible for the rup- 
Table 1. Effects of concentration of BA on length and number of shoots produced by in vitro cultured Satureja obovata juvenile explants.

\begin{tabular}{lccc}
\hline \hline BA & Main shoot & \multicolumn{2}{c}{ Axillary shoots } \\
\cline { 3 - 4 }$(\mu \mathrm{M})$ & length $(\mathrm{cm})$ & No. & Length $(\mathrm{cm})$ \\
\hline 0.00 & $1.8 \mathrm{~b}^{z}$ & $0.1 \mathrm{a}$ & $0.7 \mathrm{a}$ \\
1.11 & $1.7 \mathrm{~b}$ & $1.3 \mathrm{~b}$ & $0.9 \mathrm{a}$ \\
2.22 & $2.3 \mathrm{c}$ & $4.2 \mathrm{c}$ & $1.2 \mathrm{~b}$ \\
4.44 & $1.3 \mathrm{a}$ & $3.5 \mathrm{c}$ & $0.9 \mathrm{a}$ \\
\hline
\end{tabular}

${ }^{\mathrm{z}}$ Means separation within columns by Scheffe's tes at $P \leq 0.05$.

Table 2. Effects on three cytokinins on length and number of shoots produced by in vitro cultured Satureja obovata adult explants.

\begin{tabular}{lccc}
\hline \hline $\begin{array}{l}\text { Cytokinin } \\
(2.22 \mu \mathrm{M})\end{array}$ & $\begin{array}{c}\text { Main shoot } \\
\text { length }(\mathrm{cm})\end{array}$ & \multicolumn{2}{c}{ Axillary shoots } \\
\cline { 3 - 4 } BA & $0.9 \mathrm{a}^{\mathrm{z}}$ & No. & Length $(\mathrm{cm})$ \\
Zeatin & $1.1 \mathrm{~b}$ & $1.9 \mathrm{a}$ & $0.4 \mathrm{a}$ \\
2iP & $1.0 \mathrm{ab}$ & $0.6 \mathrm{~b}$ & $0.4 \mathrm{~b}$ \\
\hline
\end{tabular}

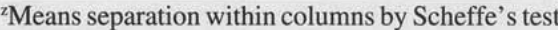
at $P \leq 0.05$.

ture of the pericarp (Bradbeer, 1988). Savory seed germination was not improved by $\mathrm{GA}_{3}$, as $60 \%$ of the control nutlets germinated vs. $40 \%$ to $90 \%$ of the seeds receiving various $\mathrm{GA}_{3}$ treatments (data not shown).

Four to 6 weeks after establishment of adult explants in vitro, 1 -cm-long shoots were obtained that could be used for multiplication experiments.

Shoot multiplication. Each axillary bud of the original juvenile propagule gave rise to a main shoot at all BA concentrations. Inclusion of BA at $2.22 \mu \mathrm{M}$ significantly increased main and axillary shoot lengths (Table 1 ), but BA at $4.44 \mu \mathrm{m}$ was inhibitory. The highest number of shoots was also observed at $2.22 \mu \mathrm{MBA}$ (Table 1). Leaf number was increased only by 1.11 and $2.22 \mu \mathrm{M}$ BA (data not shown). In the absence of BA, $86 \%$ of the propagules rooted, whereas severe inhibition of rooting was obtained in the presence of cytokinin (data not shown). The inhibition of rooting by cytokinins seems to be a general phenomenon (Murashige, 1974).

Pâques (1991) has indicated that BA could induce hyperhydration of shoots. In savory cultures, hyperhydration was not common, although at $4.44 \mu \mathrm{M} \mathrm{BA}, 8 \%$ of the cultures were affected.

Main shoot length in adult explants was slightly less in the presence of $\mathrm{BA}$ in relation to the other cytokinins; however, because it induced the highest proliferation rate (Table 2 ), this cytokinin was chosen as a standard for shoot multiplication in adult explants.

Rooting and acclimatization of plants. The presence of IBA throughout the 5-week rooting period increased percent rooting of juvenile plants, as well as the number of roots per (rooted) shoot (data not shown); however, roots were abnormal and very small, negatively affecting plant survival during the acclimatization phase.

Maene and Debergh (1983) have pointed out the advantages of directly rooting microcuttings under ex vitro conditions. Savory microcuttings performed very well in the greenhouse phase and $100 \%$ rooting was obtained after 5 weeks in the acclimatization tunnels; moreover, all plants showed numerous adventitious roots. At 10 weeks, plants reached an average height of $16 \mathrm{~cm}$ with eight axillary shoots, while after 15 weeks, the young plants showed similar traits to individuals growing under field conditions, e.g., long main roots, numerous secondary roots, woody stem bases, and a marked tendency for runner production ( $25 \%$ of the plants produced runners).

After 5 weeks, $90 \%$ and $100 \%$, respectively, of the adult shoots incubated for $3 \mathrm{~d}$ in solid or liquid medium containing auxin rooted; by contrast, only $65 \%$ did so in basal medium. Differences among treatments were significant at $P \leq 0.05$. Thus, in this species, exogenous auxin for short time periods is beneficial for rooting. Our results confirm those of Jarvis (1986) concerning the lower auxin requirements during the root elongation process. Generally, low nutrient levels enhance root formation (Blazich, 1988); in this rooting medium, the level of MS macroelements was reduced to $0.3 \times$, and this probably also had a positive effect on rooting. The better results obtained when shoots were exposed to auxincontaining liquid medium may be explained by the improved supply of nutrients, hormones, and oxygen under these conditions (George, 1993). More than $95 \%$ of adult rooted plants were acclimatized successfully in the greenhouse (Fig. 1). In contrast, attempts to acclimatize adult nonrooted shoots directly in vivo were much less successful, with survival rates lower than $50 \%$.

Oil composition of micropropagated savory plants is similar to that of plants growing in the field (Arrebola, 1992). In Satureja montana, however, Cazin et al. (1985) detected noticeable variations in oil composition between micropropagated material and the corresponding mother plants in some of the chemotypes they studied; these differences were apparently caused by rejuvenation phenomena occurring in the micropropagated

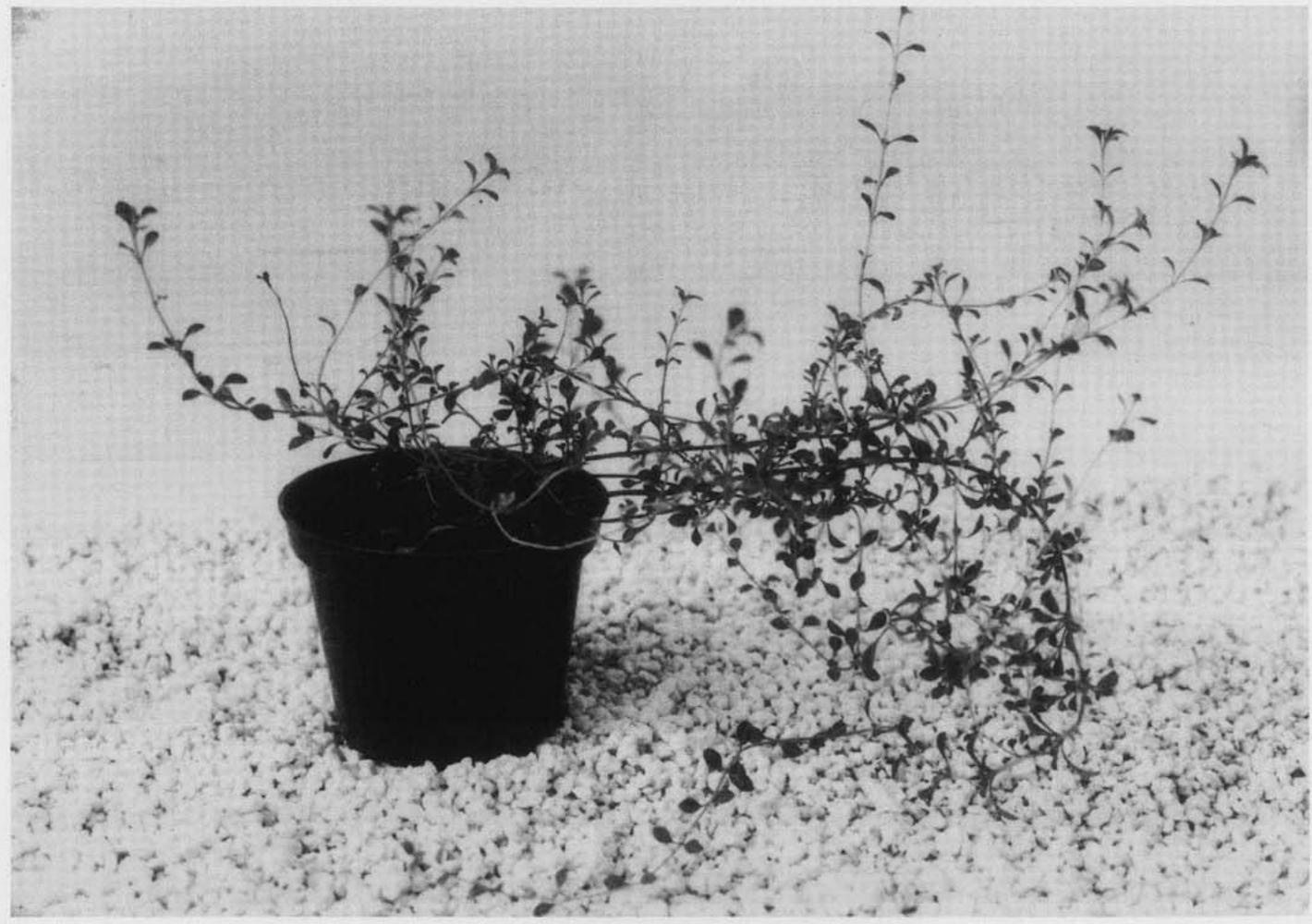

Fig. 1. Micropropagated adult savory (Satureja obovata Lag.) plant after 15 weeks under ex vitro conditions. 
material that could be related to the inclusion of $\mathrm{GA}_{3}$ in the culture medium. This hormone has been found to induce juvenile traits in several species (Zimmerman et al., 1985). Ours is the first report of successful micropropagation of adult Satureja obovata and the procedure could be used for propagation of savory genotypes selected for outstanding oil production or for its value to the apiculture industry.

\section{Literature Cited}

Arrebola, M.L. 1992. Estudio botánico y farmacoquímico de Satureja obovata Lag., Thymus serpylloides Bory subsp. serpylloides y Th. serpylloides subsp. gadorensis (Pau) Jalas. $\mathrm{PhD}$ Diss., Univ. of Granada, Spain.

Bajaj, Y.P.S., M. Furmanowa, and O. Olszowska. 1988. Biotechnology of the micropropagation of medicinal and aromatic plants, p. 60-103. In: Y.P.S. Bajaj (ed.). Biotechnology in agriculture and forestry 4 . Medicinal and aromatic plants I. Springer-Verlag, Berlin.

Barceló, A. 1995. Micropropagación de aguacate (Persea americana Mill). Aspectos histológicos del proceso de vitrificación. PhD Diss., Univ. of

\section{Málaga, Spain.}

Blazich, F.A. 1988. Mineral nutrition and adventitious rooting, p. 61-69. In: T.A. Davis, B.E. Haissig, and N. Sankhala (eds.). Adventitious root formation in cuttings. Dioscorides Press, Portland, Ore.

Bradbeer, J.W. 1988. Seed dormancy and germination. Blackie, London.

Cazin, C., R. Jonard, P. Allain, and J. Pellecuer. 1985. L'evolution de la composition des huiles essentielles chez divers chémotypes de Sarriette des montagnes (Satureia montana L.) obtenus par l'isolement in vitro des apex. C.R. Acad. Sci. Paris, 300, Série III. 6:237-240.

Cruz, T., M.M. Cabo, J. Jiménez, and A. Zarzuelo. 1990. Composition and pharmacological activity of the essential oil of Satureja obovata. II. Spasmolytic activity. Fitoterapia 61:247-251.

George, E.F. 1993. Plant propagation by tissue culture. Part I. The technology. Exegetics, Edington, England.

Hartmann, H.T., D.E. Kester, and F.T.Davies. 1990. Plant propagation. Principles and practices. 5th ed. Prentice-Hall, Englewood Cliffs, N.J.

Jarvis, B.C. 1986. Endogenous control of adventitious rooting in non-woody cuttings, p. 191222. In: M.B. Jackson (ed.). New root formation in plants and cuttings. Martinus Nijhoff,
Dordrecht, The Netherlands.

Maene, L.M. and P.C. Debergh. 1983. Rooting of tissue cultured plants under in vivo conditions. Acta Hort. 131:201-208.

Murashige, T. 1974. Plant propagation through tissue cultures. Annu. Rev. Plant Physiol. 25:135166.

Murashige, T. and F. Skoog. 1962. A revised medium for rapid growth and bioassays with tobacco cultures. Physiol. Plant. 15:473-497.

Navarro, C., A.Zarzuelo, J. Jiménez, and J.Quevedo. 1989. Composition and pharmacological activity of the essential oil of Satureja obovata collected in four different localities. Fitoterapia 60:277-281.

Pâques, M. 1991. Vitrification and micropropagation: Causes, remedies and prospects. Acta Hort. 289:283-290.

Socorro, O. 1987. Flora melífera, p. 1379-1404. In: M. Ferrer (ed.). Sierra Nevada y La Alpujarra. vol. 4. Editorial Andalucía, Granada.

Sokal, R.R. and F.J. Rohlf. 1981. Biometry. The principles and practice of statistics in biological research. W.H. Freeman, San Francisco.

Zimmerman, R.H., W.P. Hackett, and R.P. Pharis. 1985. Hormonal aspects of phase change and precocious flowering. Encycl. Plant Physiol. 11:79-115. 